\title{
EVALUATION OF LACTIC ACID BACTERIA GROWTH DURING AUTOCHTHONOUS ALBANIAN KALLMET WINE PRODUCTION WITH SPONTANEOUS AND INOCULATED FERMENTATIONS
}

\author{
Rozeta Hasalliu ${ }^{1}$
}

\begin{abstract}
The grape used in wine making has many wild microorganisms like lactic acid bacteria, yeast, acetic acid bacteria. During the alcoholic fermentation, the evaluation of these microorganisms depends on their activity. There is an interaction between yeast and lactic acid bacteria during this period of wine making. In this study, we have made wine from the autochthonous Albanian grape Kallmet variety using the spontaneous fermentation and inoculated fermentation with the yeast Saccharomyces bayannus. Yeasts carry out the alcohol fermentation, and lactic acid bacteria make malolactic fermentation in wine. With this fermentation, lactic acid bacteria convert malic acid to lactic acid, reducing the acidity of the wine and create a microbiological stability. During the alcoholic fermentation, the evaluation of lactic acid bacteria is not required. The aim of our study is to evaluate the first quantity of lactic acid bacteria to Kallmet grape, their performance during the two fermentations, spontaneous and inoculated fermentations.
\end{abstract}

UDC Classification: 63; DOI: http://dx.doi.org/10.12955/cbup.v5.1096

Keywords: lactic acid bacteria, Albanian wine, Kallmet grape, spontaneous and inoculated fermentations.

\section{Introduction}

In Albania, some of wine producers produce wine with spontaneous fermentation, and others produce wine with inoculated yeasts that are Saccharomyces cerevisiae, Saccharomyces bayanus or a mix between two yeasts, Saccharomyces cerevisiae and Saccharomyces bayanus (Hasalliu, 2016).

Must has a low pH value (3-3.5) as well as a high sugar concentration. Therefore, it represents a very specific habitat in which the chemical and physiological conditions are changing during vinification. There are only three groups of microorganisms that are adapted to these harsh conditions: yeasts, acetic acid bacteria $(\mathrm{AAB})$ and lactic acid bacteria (LAB). These microbes also influence the wine making process itself (König et al., 2009, Petri et al., 2013).

Lactic acid bacteria can already be found on grapes. However, undamaged grapes contain less than $10^{3}$ colony-forming units (CFU)/g leading to a low initial titer in must (Lafon-Lafourcade et al., 1983). Only a few LAB species of the genera Lactobacillus (Lb.), Leuconostoc (Lc), Pediococcus (P.), Oenococcus (O.) and Weissella (W.) can grow in must, whereas carnobacteria, enterococci, lactococci, streptococci, and bifidobacteria have not been isolated from must or wine. The acetic acid bacteria Acetobacter and Gluconobacter as well as more than 90 yeast species have also been found. Yeasts convert glucose of the sugar-rich must into alcohol. Most of the yeasts will usually die out once the alcohol level reaches about 5\%, whereas more alcohol tolerant Saccharomyces species take over. Also, the CFU of LAB decreases after an initial increase from $10^{2}$ to $10^{4}-10^{5} \mathrm{CFU} / \mathrm{ml}$ during the first days of must fermentation. During alcoholic fermentation, LAB do not multiply or even disappear, except $\mathrm{O}$. oeni, which resists at low cell levels.

We studied this growth in our experiments with the Albanian grape variety Kallmet.

After alcoholic fermentation, the growth of this species is stimulated because of the released cell constituents of yeasts, which are in a stationary or death phase. At this stage, oenococci have an influence on yeast lysis by producing glycosidases and proteases (König et al., 2009)

Only some other ethanol tolerant LAB species survive in young wine or wine. Furthermore, it was found that fatty acids (hexanoic, octanoic and decanoic acid) liberated by growing yeast also have a negative effect on bacterial growth (Lonvaud-Funel et al., 1991; Hui, 1995).

\section{Relevance of $\mathrm{LAB}$ in wine and malolactic fermentation by LAB}

LAB plays an important role in wine quality. The malolactic fermentation carried out by these bacteria leads to de-acidification and stabilization of wines. $\mathrm{LAB}$ converts malate into lactate and $\mathrm{CO}_{2}$ after alcoholic fermentation. This so called malolactic fermentation primarily leads to biological deacidification, but also to flavor modifications and microbial stabilization. Therefore, it has a positive effect on wine quality (Liu, 2002).

\footnotetext{
${ }^{1}$ Faculty of Biotechnology and Food, Agricultural University of Tirana, Albania, hasalliur@yahoo.com
} 
In addition to malate, lactic acid bacteria also metabolize tartrate and citrate, which also belong to the main acids of must. Citrate is metabolized to lactate, acetic acid, $\mathrm{CO}_{2}$, and acetoin. According to Radler and Yannissis (1972), tartrate can be converted to lactate, acetate, and $\mathrm{CO}_{2}$ by homofermentative $\mathrm{LAB}$ (e.g., Lb. plantarum) and to acetate and $\mathrm{CO}_{2}$ or fumaric acid (succinic acid) by heterofermentative LAB (e.g. Lb. brevis) (Llauberes et al, 1990; Duenas et al, 2003).

Even though malolactic fermentation can occur spontaneously, O. oeni is often used as a bacterial starter culture. Because of its high tolerance to ethanol and acidity, this species is the preferred starter culture applied for the reduction of the malic acid content (Brandolini et al., 2002). Especially in northern countries, where must can have a high acidity, the biological reduction with such starter cultures is an important step in vinification. However, the malolactic enzyme has also been found in many other lactic acid bacteria occurring in wine (e.g., Lb. casei, Lb. brevis, Lb. buchneri, Lb. delbrueckii, Lb. hilgardii, Lb. plantarum and Lc. mesenteroides (Schiitz and Radler, 1984).

The malolactic fermentation and the consumption of nutrients (hexoses and pentoses), as well as the production of antimicrobial components (De Vuyst and Vandamme, 1994), can lead to more stable wines. Lactic acid bacteria potentially produce acetic acid, higher concentrations of $\mathrm{CO}_{2}, \mathrm{H}_{2} \mathrm{O}_{2}$, diacetyl, pyroglutamic acid and bacteriocins, which inhibit the growth of other bacterial and yeast species (Rammelberg and Radler, 1990; Blom and Mortvedt, 1991). For example, it is known that the bacteriocin brevicin from Lb. brevis inhibits the growth of O. oeni and P. damnosus (Rammelberg and Radler, 1990).

\section{Spoilage by LAB (e.g., mousiness, ropiness)}

In Albania, we do not have studies about the growth and the effects of lactic acid bacteria in wine.

Nevertheless, the role of LAB in winemaking is ambivalent as this fermentation is only occasionally desirable during vinification in some wines. Exopolysaccharide production leads to graisse of the must, which causes problems during filtration. Different strains of P. damnosus, P. parvulus or Leuconostoc mesenteroides are well known for the formation of exopolysaccharide slimes, which lead to so called ropy wines (Vincenzini et al., 2009; König et al., 2009). Viscosity, which is influenced by many factors such as the ethanol concentration and temperature, becomes apparent at $10^{7} \mathrm{CFU} / \mathrm{ml}$. Especially P. damnosus increases the viscosity by producing a glucose homopolymer.

Lactobacilli can also cause a loss of color (up to $30 \%$ ) after malolactic fermentation. This is due to $\mathrm{pH}$ changes that cause a shift in the equilibrium of anthocyanins, which contribute to the stability of color in wine.

Several LAB are also involved in the generation of numerous off-flavors, because they can produce acetic acid, diacetyl, acetoin, 2,3-butanediol, ethyl lactate, diethyl succinate, acrolein, mannitol and compounds that form the geranium note or mousy-off flavor (König et al., 2009; Petri et al., 2013).

Mousy-off flavor or mousiness is a smell reminiscent of mice. Lactobacilli such as Lb. brevis, Lb. hilgardii and $\mathrm{Lb}$. fermentum produce acetyl-tetrahydropyridine (perception threshold: $1.6 \mathrm{ng} / 1$ ) from ethanol and lysine. Acetyl-pyrroline and ethyl-tetrahydropyridine can also contribute to this off-flavor (Vincenzini et al., 2009; Nakayama and Sonomoto, 2002).

Diacetyl and acetoin can be formed by the metabolism of citrate if the excess of pyruvate is reduced to lactic acid.

Fructose is reduced to mannitol or converted to erythritol and acetate. When Lb. plantarum is grown on mannitol, oxaloacetate can also function as electron acceptor leading to the formation of succinic acid (Chen and McFeeters, 1986).

Glycerol is converted to propanediol and acrolein leading to bitterness (Schiitz and Radler, 1984).

O. oeni can also produce off-flavors due to the metabolism of cysteine and methionine. Hence, cysteine is transformed into hydrogen sulfide or sulfanyl ethanol and methionine into dimethyl disulfide, propanol, and propionic acid. The latter has an earthy, red-berry fruit flavor (RibereauGayon et al., 2006).

Health hazards due to LAB (e.g., biogenic amines, ethylcarbamate)

Biogenic amine production (e.g., tyramine, histamine or putrescine), is also mainly caused by microbiological activities of some LAB strains during vinification. O. oeni, P. cerevisiae, and Lb. 
hilgardii are examples of producers of biogenic amines (Landete et al., 2005; Mangani et al., 2005; Sebastian et al., 2011; Petri et al., 2013).

The most important biogenic amine is histamine, which is produced by decarboxylation of histidine. The COST Action 917 (2000-2001) of the EU "Biologically active amines in food" suggested prescriptive limits for histamine (e.g., France: $8 \mathrm{mg} / \mathrm{l}$, Germany: $2 \mathrm{mg} / \mathrm{l}$ ) in wines. Biogenic amines can cause health problems like migraine and head ache (Coton et al., 1998) and sensory defects in wine (Lehtonen, 1996). From arginine, ammonium is liberated by heterofermentative species such as Lb. higardii and O. oeni, but also by facultatively heterofermentative species like Lb. plantarum.

Ethyl carbamate, which is probably carcinogenic, is produced from urea and ethanol by O. oeni and Lb. hilgardii (Uthurry et al., 2006). Alcoholic fermentation must prevail against malolactic fermentation in the first days of fermentation. The growth of lactic acid bacteria in the first days of fermentation may cause shortcomings of the wine.

The aim of our study is to evaluate the first quantity of lactic acid bacteria to Kallmet grape, their performance during the two fermentations, (spontaneous and inoculated fermentations).

\section{Materials and methods}

$100 \mathrm{~kg}$ of Kallmet grape (Figure 1) were used to produce Kallmet wine with spontanenous fermentation and fermentation inoculated with Sacharomyces bayanus yeast.

For this work, the grape of variety Kallmet was harvested in the village of Kallmet (Lezhe) at $18^{\circ}$ Brix. The quantity was divided into 2 lots of $50 \mathrm{~kg}$ each (K1 and $\mathrm{K} 2)$. The analytical parameters analyzed to the grape must were: $\mathrm{pH}$, total acidity, $\%$ of sugar content and chromatic characteristics. After the crushing, each lot was treated with $3 \mathrm{~g} / \mathrm{hL}$ of $\mathrm{SO}_{2}$ and the $\mathrm{K} 1$ lot was also added 2,5g/kg of medium toasted oak chips.

Both lots were placed to macerate in cold temperature $5^{\circ} \mathrm{C}$ for 72 hours. After the cold maceration, the $\mathrm{K} 1$ lot was inoculated with Saccharomyces bayanus BC at $20 \mathrm{~g} / \mathrm{hL}$ rate, while the $\mathrm{K} 2$ lot was left to ferment spontaneously. Both fermentations lasted six days and after the racking of the wine from the skins both lots were treated with $3 \mathrm{~g} / \mathrm{hL}$ of $\mathrm{SO}_{2}$ and held in storage for the second fermentation to take place.

For microbiological analysis MRS medium was prepared, sterilized in an autoclave in $121^{\circ} \mathrm{C}$ for 15 minutes, and spread out in Petri dishes.

Figure 1: Kallmet grape (Autochthonous Albanian grape variety)

$25 \mathrm{ml}$ of wine from two fermentations was homogenized in $225 \mathrm{ml}$ of peptone water. Five tubes were filled with $9 \mathrm{ml}$ of peptone water, and $1 \mathrm{ml}$ from the homogenized wine was placed in the first tube, 1 $\mathrm{ml}$ from the first tube was placed in the second tube and in the same manner until the fifth tube. Finally, five dilutions were prepared: $10^{-1}, 10^{-2}, 10^{-3}, 10^{-4}, 10^{-5} .1 \mathrm{ml}$ from each tube was placed in Petri dishes with MRS medium. Petri dishes with MRS medium were incubated in a thermostat at $30^{\circ} \mathrm{C}$. After 48-72 hours, Petri dishes were taken from the thermostat, and lactic acid bacteria colonies were counted.

\section{Results and Discussions}

The results of Kallmet wine produced in this study for total acidity were $5.5 \pm 0.08$ for K1 samples (inoculated fermentation with S. bayanus) and $6.1 \pm 0.05$ for K2 (spontaneous fermentation). The results for $\mathrm{pH}$ of the Kallmet wine were $4.12 \pm 0.02$ for K1 wine (inoculated fermentation with $\mathrm{S}$. 
bayanus) and $3.98 \pm 0.02$ for $\mathrm{K} 2$ wine with spontaneous fermentation). The results for the $\%$ of alcohol of Kallmet wine was $11.9 \pm 0.03$ for K1 wine (inoculated fermentation with S. bayanus) and $12 \pm 0.02$ for $\mathrm{K} 2$ wine (spontaneous fermentation).

Due to its tolerance against ethanol and acidic conditions, LAB (Lactic Acid Bacteria) can grow in must. During the first days of must fermentation, the CFU of LAB increased from $10^{5}$ to $10^{6}-10^{7}$ per $\mathrm{ml}$ (Table 1).

\begin{tabular}{|l|l|l|l|}
\hline \multicolumn{3}{|c|}{ Table 1: The graphic of lactic acid bacteria number during two fermentations } \\
\hline & $\begin{array}{l}\text { Days of } \\
\text { fermentation }\end{array}$ & $\begin{array}{l}\text { K1(Kallmet Wine } \\
\text { inoculated with S. } \\
\text { bayanus) cfu/ml }\end{array}$ & $\begin{array}{l}\text { K2 (Kallmet wine with } \\
\text { spontaneous fermentation) } \\
\text { cfu/ml }\end{array}$ \\
\hline 1 & $2 \times 10^{5}$ & $2 \times 10^{5}$ \\
\hline 6 & $1.1 \times 10^{6}$ & $1.7 \times 10^{6}$ \\
\hline 8 & $7 \times 10^{6}$ & $7.1 \times 10^{6}$ \\
\hline 9 & $8 \times 10^{6}$ & $1.8 \times 10^{7}$ \\
\hline 10 & $2.8 \times 10^{6}$ & $2.2 \times 10^{7}$ \\
\hline 11 & $1.2 \times 10^{6}$ & $4.7 \times 10^{6}$ \\
\hline 12 & $6.7 \times 10^{6}$ & $1.3 \times 10^{6}$ \\
\hline
\end{tabular}

The initial quantity of lactic acid bacteria is the same for the two samples K1 and K2 because it was the first day of fermentation and yeasts were just added and they have not started their activity yet. This quantity is the first quantity that is in Kallmet grape.

With the start of fermentation the number of lactic acid bacteria in K2 samples, (wine without inoculated yeasts) was higher $\left(1.8 \times 10^{7}\right.$, day 9) than $\mathrm{K} 1$ samples $\left(8 \times 10^{6}\right.$, day 9) of wine with inoculated yeasts Saccharomyces bayanus.

On the 10th day of fermentation, the number of lactic acid bacteria in K2 samples, (wine without inoculated yeasts) was also higher $\left(2.2 \times 10^{7}\right)$ than in $\mathrm{K} 1$ samples $\left(2.8 \times 10^{6}\right)$ of wine with inoculated yeasts Saccharomyces bayanus (Figure 2). This is because inoculated yeasts inhibit the growth of lactic acid bacteria. Yeasts cells are bigger than lactic acid bacteria cells, and they are competitive against lactic acid bacteria for the nutrient. Yeasts produce secondary components like toxic components that inhibit the growth of lactic acid bacteria and others spoilage bacteria for the wine like acetic acid bacteria or spoilage yeasts.

Figure 2: Lactic acid bacteria during spontaneous fermentation K1 (series 1) and inoculated fermentation K2 (Series 2)

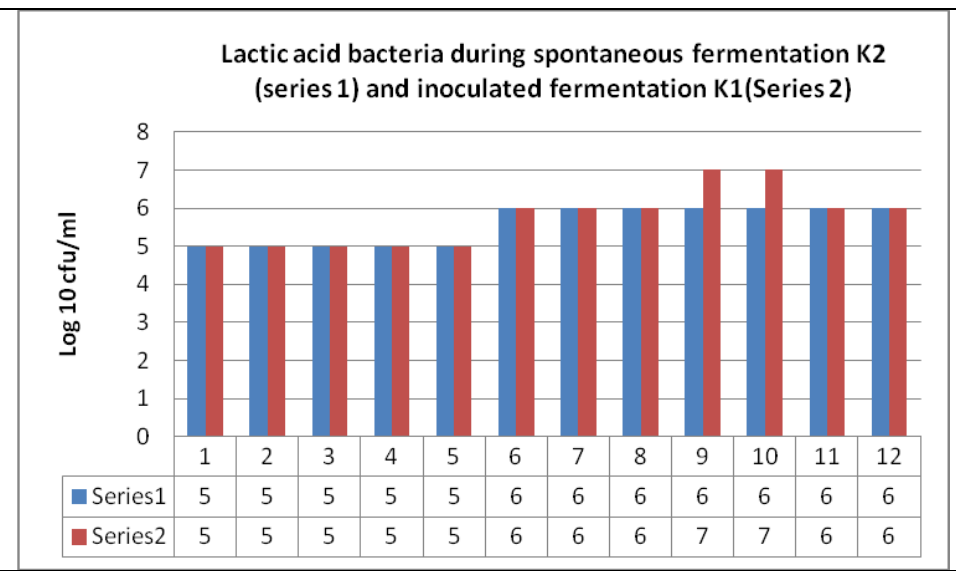

Source: Author

Lactic acid bacteria influence the flavor of wine because they can produce acetic acid, diacetyl, acetoin, 2,3-butanediol, ethyl lactate, diethyl succinate and acrolein.

\section{Conclusions}

Lactic acid bacteria are present in grape, must and wine, but their presence during alcoholic fermentation must not influence the activity of yeast for the normal alcoholic fermentation. The 
activity and the growth of the number of lactic acid bacteria is be more desirable after alcoholic fermentation to avoid a stuck of alcoholic fermentation.

From the microbiological analyses of two samples K1 (Kallmet wine with inoculated yeasts Saccharomyces bayanus) and K2 (Kallmet wine without inoculated yeasts Saccharomyces bayanus), the initial number of lactic acid bacteria was $2 \times 10^{5} \mathrm{CFU} / \mathrm{ml}$ but during the spontaneous fermentation the number of lactic acid bacteria is higher than in wine inoculated with S. bayanus in days 9 and 10 of fermentations.

Inoculated yeasts Sacharomyces bayanus, therefore, cause the inhibition of lactic acid bacteria during the process of fermentation, during the production of Kallmet wine with autochthonous Kallmet grape.

\section{References}

Blom H, Mortvedt C (1991). Anti-microbial substances produced by food associated microorganisms. Biochem Soc Trans 19:694-698

Brandolini, V., Romano, P., Maietti, A., Caruso, M., Tedeschi, P., Mazzota, D., 2002. Automated multiple development method for determination of glycerol produced by wine yeast. World Journal of Microbiology and Biotechnology 18, 481485 .

Coton E, Rollan G, Bertrand A, Lonvaud-Funel A (1998). Histamine-producing lactic acid bacteria in wines: early detection, frequency, and distribution. Am J Enol Viticult 49:199-204.

De Vuyst L, Vandamme E (1994). Bacteriocins of lactic acid bacteria: Microbiology, genetics and applications

Duenas M, Munduate A, Perea A, Irastorza A (2003): Exopolysaccharide production by Pediococcus damnosus 2.6 in a semidefined medium under different growth conditions. Int J Food Microbiol 87:113-120

Hasalliu R, Gozhdari K, Meta F, Kongoli R (2016): "Evaluation of yeasts growth during production of Kallmet wine, with spontaneous fermentation and inoculated fermentation with Saccharomyces bayanus yeast" Albanian j. agric. sci., ISSN: 2218-2020 pp. $168-171$

Hui, Y.H (1995): "Food Biotechnology, Microorganisms".

Chen K-H, Mcfeeters Rf. (1986). Utilization of electron-acceptors for anaerobic metabolism by Lactobacillus plantarum. Enzymes and intermediates in the utilization of citrate. Food Microbiol 3:83-92

Kantinakallmeti.(2017). http://kantinakallmeti.com/images/rrushi.jpg

König H, Unden G, Fröhlich J. (2009). "Biology of Microorganisms on Grapes, in Must and in Wine"

Lafon-Lafourcade S, Carre E, Ribereau-Gayon P. (1983) Occurrence of lactic-acid bacteria during the different stages of vinification and conservation of wines. Appl Environ Microbiol 46:874-880

Landete Jm, Ferrer S, Pardo I (2005). Which lactic acid bacteria are responsible for histamine production in wine? J Appl Microbiol 99:580-586

Lehtonen P (1996) Determination of amines and amino acids in wine - a review. Am J Enol Vitic 47:127-133

Liu S.Q., (2002). Malolactic fermentation in wine - beyond acidification. J. Appl. Microbiol. 92, 589-601.

Llauberes Rm, Richard B, Lonvaud-Funel A, Dubourdieu D (1990): Structure of an exocellular beta-D-glucan from Pediococcus sp, a wine lactic bacteria, Carbohydr Res 203:103-107

Lonvaud-Funel A, Joyeux A, Ledoux O (1991). Specific enumeration of lactic-acid bacteria in fermenting grape must and wine by colony hybridization with nonisotopic DNA probes. J.Appl Bacteriol 71:501-508

Mangani S, Guerrini S, Granchi L, Vincenzini M (2005). Putrescine accumulation in wine: role of Oenococcus oeni. Curr Microbiol 51:6-10

Nakayama J, Sonomoto K (2002). Cell-to-cell communication in lactic acid bacteria. J Japan Soc Biosci Biotechnol Agrochem 76:837-839

Petri A., Pfannebecker J., Frolich J., Konig H. (2013). '’Fast identification of wine related lactic acid bacteria by multiplex PCR“. Food microbiology 33: 48-54.

Radler F, Yannissis C. (1972). Decomposition of tartrate by lactobacilli. Arch Microbiol 82:219-239

Rammelberg M, Radler F (1990). Antibacterial polypeptides of Lactobacillus species. J Appl Bacteriol 69:177-184

Ribereau-Gayon P, Dubourdieu D, Doneche B, Lonvaud A. (2006). Handbook of enology, 2nd ed., vol. 1, The microbiology of wine and vinifications. John Wiley, Chichester

Sebastian P., Herr P., Fischer U., Koenig H. (2011). 'Molecular Identification of lactic Acid bacteria occurring in Must and Wine“. S. Afr. J. Enol. Vitic., Vol. 32, No.2

Schiitz H, Radler F. (1984). Anaerobic reduction of glycerol to propanediol-1.3 by L. brevis and L. buchneri. Syst Appl Microbiol 5:169-178

Uthurry Ca, Suarez Lepe Ja, Lombardero J, Garcia Del Hierro J. (2006). Ethyl carbamate production by selected yeasts and lactic acid bacteria in red wine. Food Chem 94:262-270

Vincenzini M, Romano P., Farris G.A. (2009): "Microbiologia del vino". 